\title{
Nitric Oxide Mediates Murine Cytomegalovirus-associated Pneumonitis in Lungs That Are Free of the Virus
}

\author{
Kazuo Tanaka, Hiroe Nakazawa, ${ }^{*}$ Keiko Okada, Kazuo Umezawa, Naoto Fukuyama, ${ }^{*}$ and Yasuhiro Koga \\ Department of Infectious Diseases and *Department of Physiological Science, Tokai University School of Medicine, Bohseidai, Isehara, \\ Kanagawa 259-11, Japan
}

\begin{abstract}
4 wk after intraperitoneal inoculation of $0.2 \mathrm{LD}_{50}(50 \%$ lethal dose) of murine cytomegalovirus (MCMV) in adult $\mathrm{BALB} / \mathrm{c}$ mice, MCMV remained detectable in the salivary glands, but not in the lungs or other organs. When the $T$ cells of these mice were activated in vivo by a single injection of anti-CD3 monoclonal antibody, interstitial pneumonitis was induced in the lungs that were free of the virus with an excessive production of the cytokines. In the lungs of such mice persistently infected with MCMV, the mRNA of the cytokines such as IL-2, IL-6, TNF- $\alpha$, and IFN- $\gamma$ were abundantly expressed $3 \mathrm{~h}$ after the anti-CD3 injection, and the elevated levels continued thereafter. A marked expression of inducible nitric oxide synthetase (iNOS) was then noted in the lungs, suggesting that such cytokines as TNF- $\alpha$ and IFN- $\gamma$ may have induced iNOS. Although the increase in NO formation was demonstrated by the significant elevation of the serum levels of nitrite and nitrate, the interstitial pneumonitis was not associated with either increased superoxide formation or peroxynitrite-induced tyrosine nitration. Nevertheless, the administration of an NO antagonist also alleviated the interstitial pneumonitis provoked by antiCD3 mAb. Based on these findings, it was concluded that MCMV-associated pneumonitis is mediated by a molecule of cytokine-induced NO other than peroxynitrite. (J. Clin. Invest. 1997. 100:1822-1830.) Key words: cytomegalovirus • interstitial pneumonitis $\cdot$ cytokine $\cdot$ nitric oxide $\bullet$ inducible nitric oxide synthetase
\end{abstract}

\section{Introduction}

Cytomegalovirus (CMV) $)^{1}$ causes various inflammatory diseases such as encephalitis, pneumonitis, retinitis, hepatitis, gas-

\footnotetext{
Address correspondence to Kazuo Tanaka, M.D., Ph.D., Department of Infectious Diseases, Tokai University School of Medicine, Bohseidai, Isehara, Kanagawa, 259-11, Japan. Phone: 81-463-93-1121 ext. 2590; FAX: 81-463-94-2976; E-mail: tanakaka@is.icc.u-tokai.ac.jp

Received for publication 22 April 1997 and accepted in revised form 1 August 1997.
}

1. Abbreviations used in this paper: BALF, bronchoalveolar lavage fluid; CMV, cytomegalovirus; iNOS, inducible nitric oxide synthetase; L-NAME, $N^{\mathrm{G}}$-nitro-L-arginine methyl ester; MCMV, murine cytomegalovirus; NO, nitric oxide; PBN, phenyl $\mathrm{N}$-tert-butyl nitrone; $\mathrm{XD}$, xanthine dehydrogenase; $\mathrm{XO}$, xanthine oxidase.

J. Clin. Invest.

(C) The American Society for Clinical Investigation, Inc. 0021-9738/97/10/1822/09 \$2.00

Volume 100, Number 7, October 1997, 1822-1830

http://www.jci.org tritis, and colitis, and thus raises serious concern, especially in immunocompromised patients such as AIDS patients and organ transplant recipients. So far, it has been shown that immunosuppression, which is induced either by immunosuppressive agents or HIV, rendered the host's immune system incapable of arresting the replication of the virus. However, in CMV-associated interstitial pneumonitis, it has been revealed recently that the CMV replication per se in the lung tissue is neither a triggering factor nor an aggravating factor for pneumonitis, but instead the host's immune system is considered to play a key role in the pathogenesis of the disease (1-3). In AIDS patients, whose immune systems are impaired, CMV-associated interstitial pneumonitis is uncommon even when CMV is detectable in bronchoalveolar lavage fluid (4-6). On the other hand, CMV-associated interstitial pneumonitis is common in organ transplant patients, whose immune systems are primarily intact. Moreover, in these recipients, hyper reactions of the immune responses such as rejection episodes and graft-versushost disease (GVHD), are shown to become risk factors for the onset of CMV-associated pneumonitis (7-8). These clinical observations thus support the possibility that CMV-associated interstitial pneumonitis may be triggered by an enhanced state of the host's immune system.

In a previous report, we have shown that murine CMV (MCMV)-associated interstitial pneumonitis was caused not by a replication of the virus per se, but by cytokines such as IFN- $\gamma$ and TNF- $\alpha$ (9). In this experimental system, interstitial pneumonitis was induced by anti-CD $3 \epsilon$ monoclonal antibody (mAb), which activates the host's T cells in vivo (10), in a mouse that received MCMV 4 wk earlier. The simultaneous injection of cyclosporin $\mathrm{A}$, which inhibits the production of various cytokines, in addition to anti-CD3, reduced the effect of the mAb, thus suggesting that cytokines are responsible for the induction of the interstitial pneumonitis. Interestingly, MCMV was undetectable in the lung even after an anti-CD3 injection. However, it remains unclear as to whether or not the cytokine(s) directly injure(s) the lung tissue, or whether such damage is done indirectly via other toxic molecules, which are presumably induced by the cytokine(s). Moreover, it has yet to be clarified as to why the lung is the major targeted organ in this model of interstitial pneumonitis. This study was performed to clarify these two issues.

Various mediators including cytokines, radicals such as $\mathrm{O}_{2}^{-}, \mathrm{H}_{2} \mathrm{O}_{2}$, nitric oxide (NO) and NO related substances, complement, and proteases have been reported to be mediators leading to inflammation in the lung (11). Considering that antiCD3, which activated T cells in vivo (10), could induce interstitial pneumonitis in MCMV infected mice in our experimental system, it was predicted that $\mathrm{T}$ cell-derived cytokines initiate a series of pathological events that lead to the production of lung-tissue toxic molecules, and finally to the occurrence of interstitial pneumonitis. In this study, among various cytotoxic mediators, we focused on $\mathrm{NO}$ and $\mathrm{NO}$-derived active mole- 
cules, as T cell-derived cytokines are known to rapidly induce inducible NO synthetase (iNOS) and NO plays a key role in tissue injury at the site of inflammation (12).

\section{Methods}

Mice. Male BALB/c mice were purchased from Japan Clea Inc. (Tokyo, Japan), and bred in specific pathogen-free conditions. A serological examination was performed every month in order to rule out any contamination of the mice in this colony with the lymphocytic choriomeningitis virus, Sendai virus, and mouse hepatitis virus.

Virus. The Smith strain of MCMV was obtained from the American Type Culture Collection (ATCC, Rockville, MD). The stock solution of MCMV was prepared as described previously (9). In brief, MCMV was passed once in the primary culture of mouse embryo cells. Next, the homogenate of the infected embryo cells was injected into male BALB/c mice. $2 \mathrm{wk}$ after infection, the salivary glands were collected and a supernatant of the homogenates was used as an MCMV stock solution. A supernatant of the homogenates of the noninfected salivary glands was used as a control for the mock infection. The virus titer was determined by a plaque assay using subconfluent 3T3/Swiss albino cells. The virus titer of the MCMV stock solution was $1 \times 10^{8} \mathrm{PFU} / \mathrm{ml}$, and $\mathrm{LD}_{50}$ of this virus stock for an adult BALB/c mouse was $5 \times 10^{5}$ PFU by intraperitoneal injection.

Agents. A monoclonal antibody against mouse CD3€ (anti-CD3 $\mathrm{mAb}$, hamster $\mathrm{IgG}$ ) was obtained by culturing hybridoma cells (clone 145-2C11) in a serum-free medium (SFM-101; Nissui Corp., Tokyo, Japan). The culture supernatant was then concentrated by precipitation using $50 \%$ ammonium sulfate, and the amount of protein in this preparation was then determined by a dye-binding assay using a protein-assay kit (Bio-Rad Laboratories, Richmond, CA). Except when indicated differently, all mice, which had been inoculated with 0.2 $\mathrm{LD}_{50}$ of MCMV 4 wk earlier, were injected intraperitoneally with 50 $\mu \mathrm{g}$ of anti-CD3 mAb. Mice were exsanguinated at $0,6,12,24$, and $48 \mathrm{~h}$ after the injection of anti-CD3 $\mathrm{mAb}$, and the organs were collected for histological examination, and biochemical and chemical analyses. Allopurinol (Sigma Chemical Co., St. Louis, MO) and lecithinized superoxide dismutase (Lethicin-SOD, reference 13), which was kindly provided by Dr. R. Igarashi and Dr. Y. Mizushima, St. Marianna University (Kawasaki, Japan) were used to examine the participation of superoxide in the pathogenesis of interstitial pneumonitis. Allopurinol, a xanthine oxidase inhibitor, was dissolved in saline and $2 \mathrm{mg}$ was simultaneously injected intraperitoneally with anti-CD3 $\mathrm{mAb}$. Lethicin-SOD was dissolved in 5\% mannitol, and injected intraperitoneally with $10,000 \mathrm{U} / \mathrm{kg}$ every $8 \mathrm{~h}$ for $2 \mathrm{~d}$, starting at the time of anti-CD3 mAb injection. $N^{\mathrm{G}}$-nitro-L-arginine methyl ester (L-NAME; Wako Pure Chemical Industries, Ltd., Osaka, Japan) and phenyl $\mathrm{N}$-tert-butyl nitorone (PBN; Aldrich Chemical Co., Milwaukee, WI), which can suppress the production of $\mathrm{NO}$ by inhibiting the induction of iNOS $(14,15)$. L-NAME and PBN were dissolved in PBS, and then the mice were injected intraperitoneally with $750 \mu \mathrm{g}$ and $9 \mathrm{mg}$ of each, respectively. These mice were then used to determine the contribution of NO to the induction of lung injury.

Light microscopy. The lungs were removed after exsanguination and then were fixed in $3.7 \%$ formaldehyde at room temperature for $18 \mathrm{~h}$. The sections were stained with hematoxylin-eosin. In order to quantify the thickening of the pulmonary septum because of interstitial pneumonitis, the reduction of the alveolar space and the increase of the interstitial septum in a visual field were measured using a computer image analyzer (VIDAS; Carl Zeiss Co., Ltd., Tokyo, Japan). The ratio of the area of alveolar space/whole areas (areas of alveolar and septum) was used as the indicator for the thickening of the alveolar septum.

Extraction of RNA. To detect the expression of various kinds of mRNA in the lung tissue, an RNA-PCR procedure was employed. RNA was extracted using ISOGEN (Nippon Gene Co. Ltd., Toyama, Japan), and all the procedures for the extraction of RNA were per- formed according to the manufacturer's manual. In brief, the organs were removed and immediately homogenized in $1.0 \mathrm{ml}$ of ISOGEN. Next, $0.2 \mathrm{ml}$ of chloroform was added to these samples, which were then shaken vigorously for $30 \mathrm{~s}$ and incubated for a few minutes at room temperature. The suspension was centrifuged at $12,000 \mathrm{~g}$ for 10 $\min$ at $4^{\circ} \mathrm{C}$. The aqueous phase was then transferred to a fresh tube, $0.5 \mathrm{ml}$ of isopropanol was added. After gently mixing, the samples were left for $10 \mathrm{~min}$ at room temperature. Then, after mixing vigorously with vortex, the sample was centrifuged to precipitate at $12,000 \mathrm{~g}$ for $10 \mathrm{~min}$ at $4^{\circ} \mathrm{C}$. The RNA precipitate was washed with $1 \mathrm{ml}$ of $75 \%$ ethanol, suspended in $0.5 \mathrm{ml}$ of diethylpyrocarbonate-treated water, and then frozen at $-70^{\circ} \mathrm{C}$ until use.

Primers and probes for RNA-PCR. The primers (sense and antisense) and probes for IL-2, IL-6, TNF- $\alpha$, IFN- $\gamma, \beta$-actin, and iNOS were all purchased from Clontech (Palo Alto, CA). The nucleotide sequences of cDNA for IL-2, IL- 6 , TNF- $\alpha$, IFN- $\gamma, \beta$-actin, and iNOS in the kits have been reported elsewhere (16-21, respectively). Their bp locations of $\left(5^{\prime}\right)$ primers, $\left(3^{\prime}\right)$ primers, and the expected sizes of the PCR products obtained using the kit are as follows: IL-2: 116-147, 498-529, 413 bp; IL-6: 34-57, 671-694, 638 bp; TNF- $\alpha$ : 285-314, 607638, 354 bp; IFN- $\gamma$ : 71-93, 508-530, 460 bp; $\beta$-actin: 25-45, 541-564, 540 bp; iNOS: 3104-3128, 3623-3647, 496 bp; RNA, which contains a corresponding cDNA, was used as the positive control.

RNA-PCR and Southern blot analysis. RNA-PCR was performed using a RNA-PCR Kit (Takara Shuzo Co. Ltd., Otsu, Shiga, Japan). In brief, $1 \mu \mathrm{g}$ of the total RNA extracted from the mouse organ was reverse transcribed using Avian Myeloblastosis Virus reverse transcriptase $(5 \mathrm{U})$ in a RNase free $\mathrm{H}_{2} \mathrm{O}$ (total $20 \mu \mathrm{l}$ ) containing 100-mM Tris- $\mathrm{HCl}$ (pH 8.3), 500-mM KCl, $5 \mathrm{mM}$ of $\mathrm{MgCl}_{2}, 0.5 \mathrm{mM}$ of dNTP mixture, and $2.5 \mathrm{mM}$ of oligo dT. After adding $50 \mu \mathrm{l}$ of mineral oil on the mixture, it was then incubated for $15 \mathrm{~min}$ at $42^{\circ} \mathrm{C}$, for $5 \mathrm{~min}$ at $99^{\circ} \mathrm{C}$ and then for another $5 \mathrm{~min}$ at $5^{\circ} \mathrm{C}$. The reaction mixture was then used for specific amplifications of cDNA, using Taq polymerase. For PCR, $2.5 \mathrm{mM}$ of $\mathrm{MgCl}_{2}, 100-\mathrm{mM}$ Tris- $\mathrm{HCl}$ (pH 8.3), 500-mM $\mathrm{KCl}, 0.5 \mathrm{U}$ of Taq polymerase, and $660 \mathrm{ng}$ of sense and antisense primers were then added to the reaction mixture (total volume; 100 $\mu \mathrm{l})$. After an initial incubation at $95^{\circ} \mathrm{C}$ for $120 \mathrm{~s}$, the mixture was incubated at $95^{\circ} \mathrm{C}$ for $60 \mathrm{~s}$, at $55^{\circ} \mathrm{C}$ for $60 \mathrm{~s}$ and at $60^{\circ} \mathrm{C}$ for $90 \mathrm{~s}$, for $35 \mathrm{cy}-$ cles. The PCR products were then electophoresed on a 1.5\% Agarose gel containing ethidium bromide. $\Phi$ X174/Hae III digest was used as a marker. A Southern transfer was done onto the GeneScreen Plus hybridization transfer membrane (Dupont-New England Nuclear, Boston, MA). Hybridization was performed for $2 \mathrm{~h}$ at $42^{\circ} \mathrm{C}$ with the probe tailed at the $3^{\prime}$ end with fluorescein dUTP, which was then detected by chemiluminescence using the ECL system (Amersham International, Buckinghamshire, UK).

Measurement of the activities of xanthine oxidase $(X O)$ and xanthine dehydrogenase $(X D)$. The activities of $\mathrm{XO}$ and $\mathrm{XD}$ were assayed by the fluorometric method (22). In brief, $1 \mathrm{ml}$ of lung homogenate was chromatographed on a Sephadex G-25 column (Pharmacia Fine Chemicals, Uppsala, Sweden) in order to exclude endogenous natural substrates. By elution with PBS at $4^{\circ} \mathrm{C}$, the fraction exhibiting the peak protein level was collected and used as the sample. The protein concentration in the sample was determined by a protein-assay kit (Bio-Rad Laboratories). The sample was then divided into two tubes $(0.5 \mathrm{ml}$ per tube). The XO activity in the sample was assayed by using pterine (final concentration, $10 \mu \mathrm{M}$; Sigma Chemical Co.) as the substrate, and the production of isoxantopterin was measured by a spectrophotometer (excitation, $345 \mathrm{~nm}$; emission, $390 \mathrm{~nm}$ ). Serially diluted isoxanthopterin (Aldrich Chemical Co.) was used to obtain a standard curve. To measure both the XO and XD activities (XO/XD activity) in a sample tube, methylene blue (final concentration, $9 \mathrm{mM}$ ), which enables XD to use oxygen, was added to the sample, and then the above reaction was carried out. The $(\mathrm{XO} / \mathrm{XD}-\mathrm{XO})$ activity was designated as the $\mathrm{XD}$ activity.

Measurement of $\mathrm{O}_{2}^{-}$generation in the bronchoalveolar lavage fluid $(B A L F)$. Under general anesthesia with pentobarbiturate, the mouse was inserted with an $18 \mathrm{G}$ needle in the trachea. Next, the 

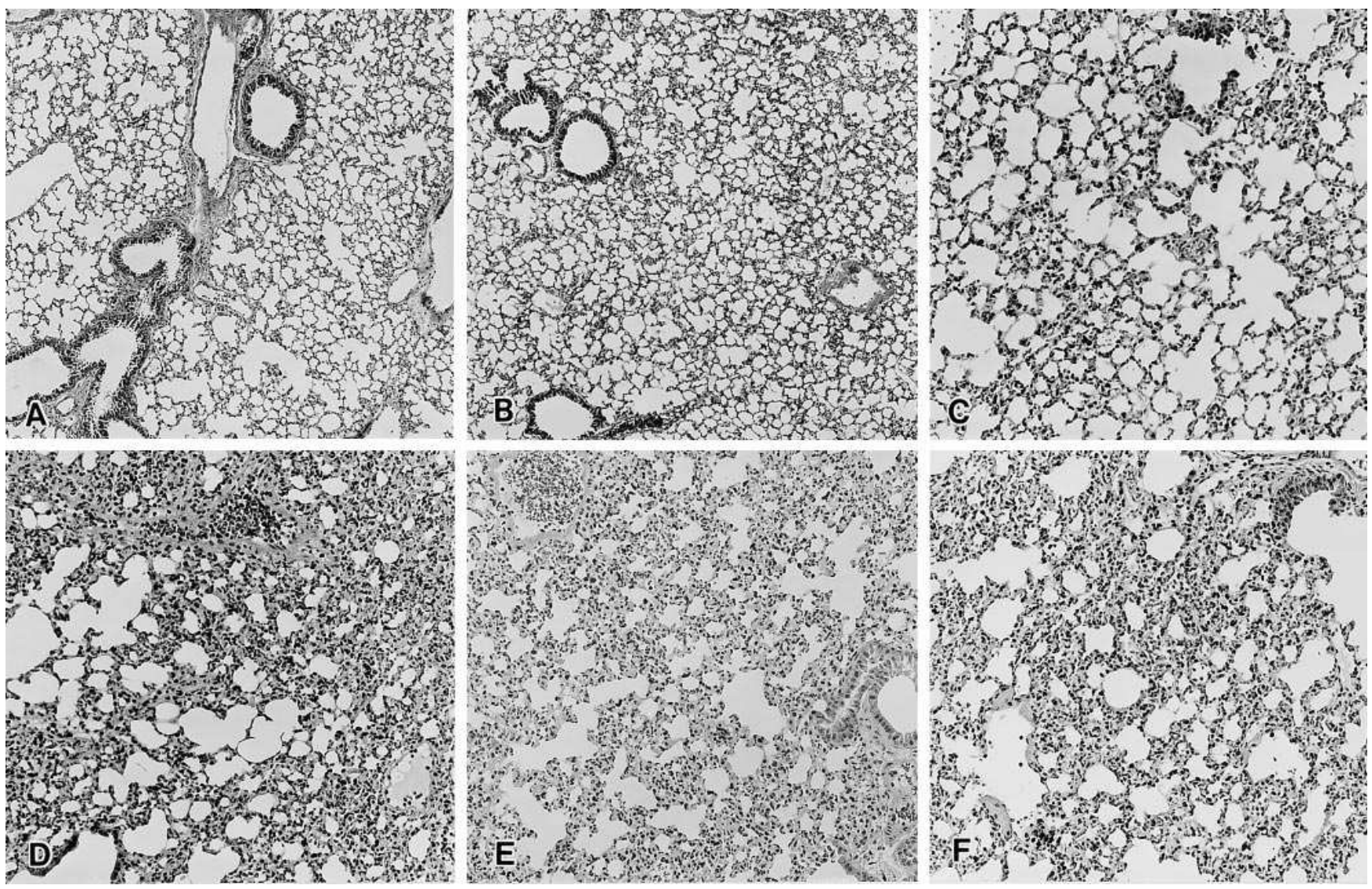

Figure 1. Histological findings of interstitial pneumonitis. BALB/c mice were inoculated either with $(B-F)$ or without $(A) 0.2 \mathrm{LD}_{50}$ of MCMV 4 wk previously. The mice, which had been inoculated with MCMV 4 wk earlier, were injected with $50 \mu \mathrm{g}$ of anti-CD3 $\mathrm{mAb}$ at $0 \mathrm{~h}(B), 6 \mathrm{~h}(C)$, $12 \mathrm{~h}(D), 24 \mathrm{~h}(E)$, and $48 \mathrm{~h}(F)$ before collecting the lungs. Hematoxylin-eosin staining. $A-B, \times 100 ; C-F, \times 150$.

bronchoalveolar space was lavaged with cold PBS, and $1 \mathrm{ml}$ of BAL was obtained. The generation of $\mathrm{O}_{2}^{-}$in the BAL was measured by chemiluminescence using luminol (Sigma Chemical Co.) at $37^{\circ} \mathrm{C}$. PICOLITE detector (Packard Instrument Co., Chicago, IL) was used to count the photons. The sample fluid $(1 \mathrm{ml})$ was incubated to obtain a basal line. Luminol (final concentration, $40 \mu \mathrm{M}$, Sigma Chemical Co.) was then added, and the photon count per minute was monitored for $10 \mathrm{~min}$, then superoxide dismutase (SOD) was added. (The SOD-inhibitable maximum counts - counts after SOD) was used as the indicator for $\mathrm{O}_{2}^{-}$generation in BALF.

Measurement of serum levels of $\mathrm{NO}_{3}{ }^{-}$(nitrate) and $\mathrm{NO}_{2}{ }^{-}$(nitrite). To measure the amount of $\mathrm{NO}$, the concentrations of $\mathrm{NO}_{3}{ }^{-}$ (nitrate) and $\mathrm{NO}_{2}{ }^{-}$(nitrite) in the serum was measured. For this measurement, the serum samples were filtered through a $3000 \mathrm{Mr}$ cut-off filter (Ultrafree C3; Japan Millipore Ltd., Tokyo, Japan) to eliminate the protein component, and then were passed through a copperplated cadmium column to reduce $\mathrm{NO}_{3}{ }^{-}$to $\mathrm{NO}_{2}{ }^{-}$. The concentration of $\mathrm{NO}_{2}{ }^{-}$was therefore determined with Griess reagent, as described previously $(23,24)$.The principle of the reaction is as follows: the Griess reagent consisted of the mixture of $0.1 \%$ naphthylenediamine dihydrochloride and $1 \%$ sulfanilamide. Diazotiation of the amine by nitrite and the coupling of the product formed an azochromophore, which was measured by the absorbance at $543 \mathrm{~nm}$.

Measurement of tyrosine nitration in the lung tissue. When NO and superoxide are cogenerated, they form peroxynitrite $\left(\mathrm{ONOO}^{-}\right)$at a diffusion limited rate. As peroxynitrite directly nitrates tyrosine of nonprotein and protein (25), nitrotyrosine in the lung tissue was measured as the index of peroxynitrite generation. The results were expressed as the ratio of nitrotyrosine to total tyrosine. For the assay, the lungs were removed after exsanguination, and immediately ho- mogenated in liquid nitrogen. Next, tyrosine and nitrotyrosine in the sample were measured by a previously described method (26). In brief, nitrotyrosine was separated using an HPLC C-18 reverse-phase column and measured with an ultraviolet detector set at $274 \mathrm{~nm}$. The peaks of tyrosine and nitrotyrosine were identified based on the retention time of authentic tyrosine and nitrotyrosine (Sigma Chemical Co.). The peak of nitrotyrosine was then further confirmed by treatment with excess $\mathrm{Na}_{2} \mathrm{~S}_{2} \mathrm{O}_{4}$, which reduces nitrotyrosine to aminotyrosine, and thus eliminates the peak of nitrotyrosine.

Statistical analysis. The statistical analysis was done using Student's $t$ test.

\section{Results}

Formation of interstitial pneumonitis after anti-CD3 mAb injection. As reported previously (9), when male BALB/c mice at 6 wk of age were inoculated with $0.2 \mathrm{LD}_{50}$ of MCMV, the viral load reached its peak at 1-2 wk, and thereafter decreased, and became detectable only in the salivary glands 4 wk after the inoculation. In the lungs, on the other hand, not only the infectious virus but also the viral genome were still undetectable at that time. As shown in Fig. 1, $A$ and $B$, the mice persistently infected with MCMV in the salivary glands did not exhibit any pathological changes in the lung. These mice were then injected intraperitoneally with anti-CD $3 € \mathrm{mAb}(50 \mu \mathrm{g})$ in order to activate the $\mathrm{T}$ cells in vivo (10). The anti-CD3 $\mathrm{mAb}$ did not induce the reappearance of infectious virus in the lungs, however, this treatment did provoke a marked degree of intersti- 
B

TNF- $\alpha$

LUNG

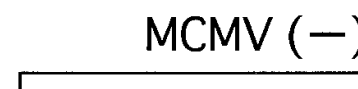

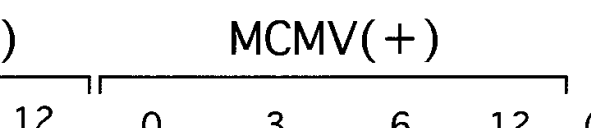

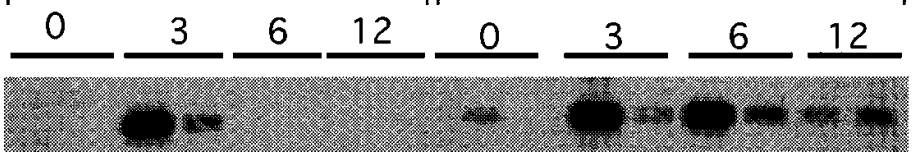
$(\mathrm{Hr})$

SPLEEN
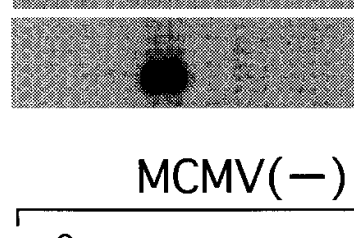

\section{IFN $-\gamma$ \\ LUNG \\ SPLEEN}

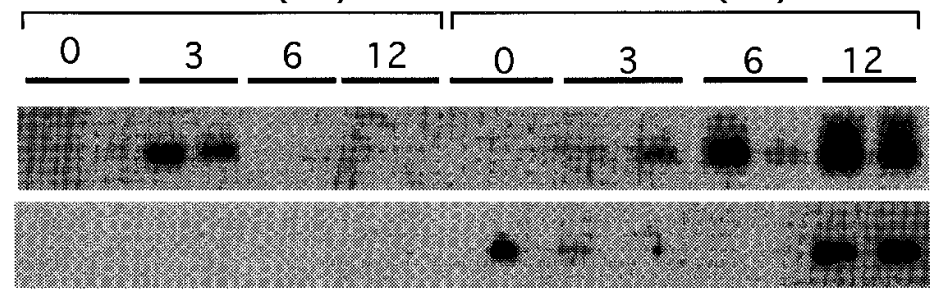

Figure 2. Expression of cytokine mRNA analyzed by RNA-PCR. The mice, which had been inoculated intraperitoneally with 0.2 $\mathrm{LD}_{50}$ of MCMV 4 wk earlier, were injected intraperitoneally with $50 \mu \mathrm{g}$ of anti-CD3 mAb. Next, the lungs $(A$ and $B)$ and the spleens $(B)$ were removed at $0,3,6$, and $12 \mathrm{~h}$ after the mAb injection to extract RNA. The expression levels of mRNA for IL-2, IL-6, TNF- $\alpha$, and IFN- $\gamma$ were examined by RNAPCR. (A) Agarose gel electrophoresis of RNA-PCR products obtained from the lungs. The products were stained with ethidium bromide. $\Phi X 174 / \mathrm{HaeIII}$ digest was used as a base pair marker. The results of the products from the two mice are shown, and similar results were also obtained in two additional experiments. $(B)$ Southern hybridization of RNA-PCR products from the lungs and the spleens. The RNA-PCR products from two animals were hybridized by a probe labeled by the ECL system. tial pneumonitis in this virus-free lung MCMV $6 \mathrm{~h}$ after mAb injection (Fig. 1, $C-F$ ). A microscopical analysis revealed the histopathological changes characteristic to interstitial pneumonitis, such that the lungs consisted of a marked thickening of the alveolar septae and infiltrated mononuclear cells (Fig. 1, $D-F$ ). As for mortality, $65 \%$ (number of dead mice per total number of $\mathrm{mAb}$ injected mice $=13 / 20$ ) of the mice died between 24 and $48 \mathrm{~h}$ after mAb injection. On the other hand, anti-CD3 did not affect the lungs of the mock infected mice at all, and none of them died even after receiving higher doses of $\mathrm{mAb}$ as reported previously (9).

Expression levels of cytokine $m R N A$. A previous report revealed that the serum levels of cytokines such as IFN- $\gamma$ and TNF- $\alpha$ in MCMV-infected mice at $12 \mathrm{~h}$ after anti-CD3 injection were almost twice the levels seen in the mock-infected mice (9). Moreover, a simultaneous injection of cyclosporin A reduced the ability of anti-CD3 $\mathrm{mAb}$ to provoke interstitial pneumonitis, thus suggesting that cytokines may participate in the development of pulmonary lesions. Thus, the next experiments were designed to confirm that a high amount of cytokines is actually produced in the lung tissue of MCMVinfected mice after anti-CD3 injection. In MCMV-infected mice, anti-CD3 mAb induced high expression levels of mRNA of IL-2, IL-6, TNF- $\alpha$, and IFN- $\gamma 3 \mathrm{~h}$ after the injection of $\mathrm{mAb}$, and such high levels thereafter continued until 6 to $12 \mathrm{~h}$ (Fig. 2 $A)$. As for TNF- $\alpha$ and IFN- $\gamma$, these results were closely correlated with those of a previous study, in which the serum levels of IFN- $\gamma$ and TNF- $\alpha$ were significantly higher in the MCMVinfected mice than those in the mock-infected mice after antiCD3 injection (9). In the mock-infected mice, on the other hand, anti-CD3 induced a transient expression of mRNA in these cytokines only $3 \mathrm{~h}$ after the injection of $\mathrm{mAb}$. Interest- 
ingly, the anti-CD3 $\mathrm{mAb}$ induced cytokine production in MCMV-infected mice was more prominent in the lung than in the spleen (Fig. 2 B), whereas the lymphocytes and other immunocompetent cells are abundant in the spleen.

Activities of $\mathrm{XO}$ and $\mathrm{XD}$ in the lung and $\mathrm{O}_{2}{ }^{-}$generation in $B A L F$. While it was confirmed that various kinds of cytokines were produced in the lung of the MCMV infected mice when their $\mathrm{T}$ cells were activated in vivo, it is still unclear as to whether or not the cytokines injured the lung tissue directly or indirectly through the production of some biologically active substances. Among them, the oxygen and nitrogen radicals were reported to cause a severe inflammation, and moreover, both TNF- $\alpha$ and IFN- $\gamma$ are known to enhance the productions of these radicals (27-33). The production of these radicals were thus examined in the following experiments. At first, the production of reactive oxygen species was examined. As the production of such major oxygen radicals as $\mathrm{O}_{2}^{-}$and $\mathrm{H}_{2} \mathrm{O}_{2}$ were mediated by XD and XO, the activities of these enzymes were assayed to predict the production levels of $\mathrm{O}_{2}^{-}$and $\mathrm{H}_{2} \mathrm{O}_{2}$. As shown in Fig. 3, the activities of both enzymes in MCMV infected mice were comparable to those in mock-infected mice at any time after the anti-CD3 mAb injection. Moreover, the treatment with allopurinol, a XO inhibitor, did not improve the mortality ratios $(75 \%, n=8$ versus $65 \%, n=20$, in an un-

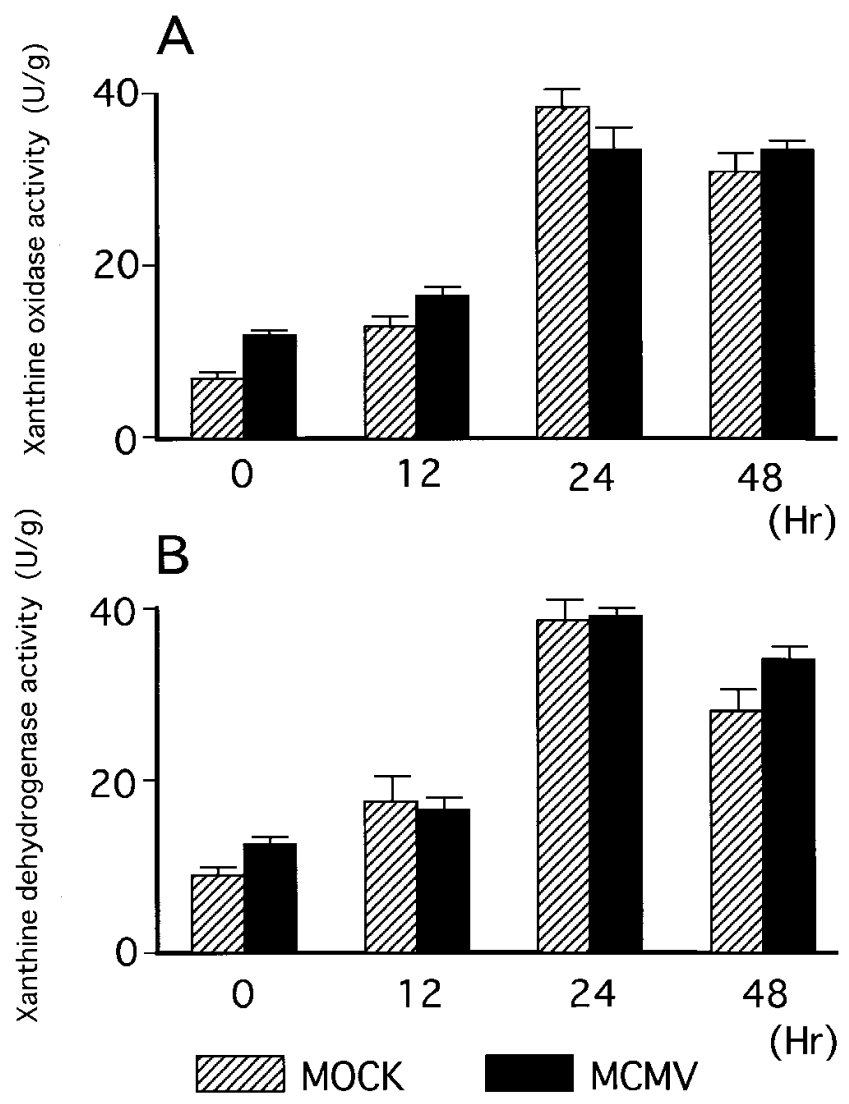

Figure 3. $\mathrm{XO}(A)$ and $\mathrm{XD}(B)$ activities in the lung tissues. The mice, which had been inoculated either with (black bar) or without (hatched bar) MCMV 4 wk earlier, were injected with anti-CD3 $\mathrm{mAb}$. Next, the lungs were removed at $0,12,24$, and $48 \mathrm{~h}$ after the injection, and then the enzyme activities were measured. The mean $\pm \mathrm{SD}, n=6$. No statistical significance was obtained between the mock and MCMV group at any time.

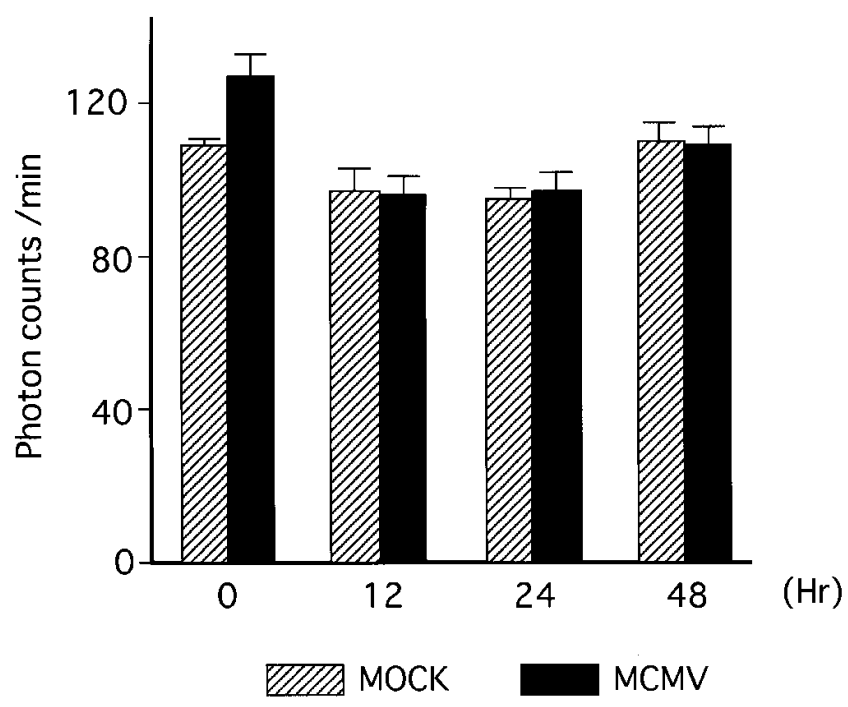

Figure 4. Superoxide $\left(\mathrm{O}_{2}^{-}\right)$generation in the BALF. The mice, which had been inoculated with MCMV, were injected with anti-CD3 $\mathrm{mAb}$, and $\mathrm{BAL}$ were collected through the needles inserted to the main bronchus of the mice at $0,12,24$, and $48 \mathrm{~h}$ after the $\mathrm{mAb}$ injection. Superoxide in BALF $(1 \mathrm{ml})$ was measured by chemiluminescence using luminol. No statistical significance was obtained between the mock and MCMV group at any time. Mean $\pm \mathrm{SD}, n=5$.

treated group). It was thus considered that the productions of $\mathrm{O}_{2}{ }^{-}$and $\mathrm{H}_{2} \mathrm{O}_{2}$ in the MCMV-infected mice after anti-CD3 injection were comparable to those in the mock-infected mice. To confirm this, the $\mathrm{O}_{2}{ }^{-}$generation in the BALF was then measured. As expected, the $\mathrm{O}_{2}^{-}$levels in BALF of MCMVinfected mice were comparable to those of the mock infected mice (Fig. 4). In addition, the treatment with lecithinized superoxide dismutase (SOD), which is a potent superoxide scavenger and its half-life $(1.7 \mathrm{~h})$ is longer than that of unmodified SOD (1.0 h, reference 13) thus expected to be more effective when administered in vivo, did not improve the mortality rate (mortality rate; $63 \%, n=8$, versus $65 \%$ in an untreated group). These results suggested that the pulmonary lesions in

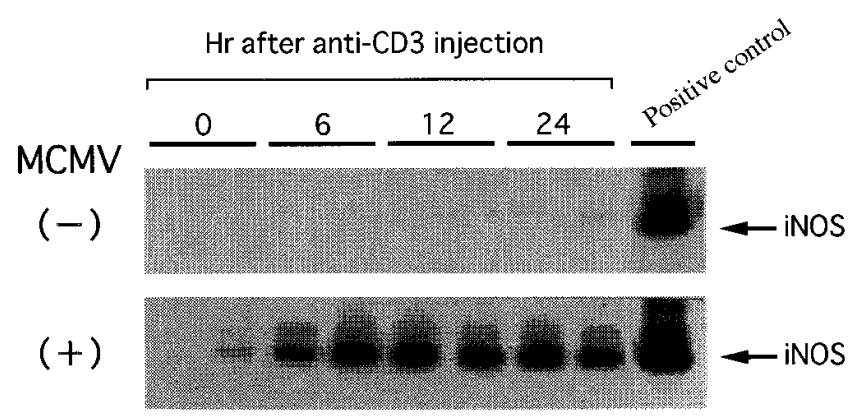

Figure 5. The expression level of iNOS mRNA analyzed by RNAPCR. The mice, which had been inoculated intraperitoneally with 0.2 $\mathrm{LD}_{50}$ of MCMV 4 wk earlier, were injected intraperitoneally with 50 $\mu \mathrm{g}$ of anti-CD3 $\mathrm{mAb}$. Next, the lungs from two mice were removed at $0,6,12$, and $24, \mathrm{~h}$ after the mAb injection, while the RNA were extracted for RNA-PCR. The findings for Southern hybridization using the ECL system are shown. Similar results were also obtained in two additional experiments. Standard iNOS mRNA in the kit was used as a positive control. 


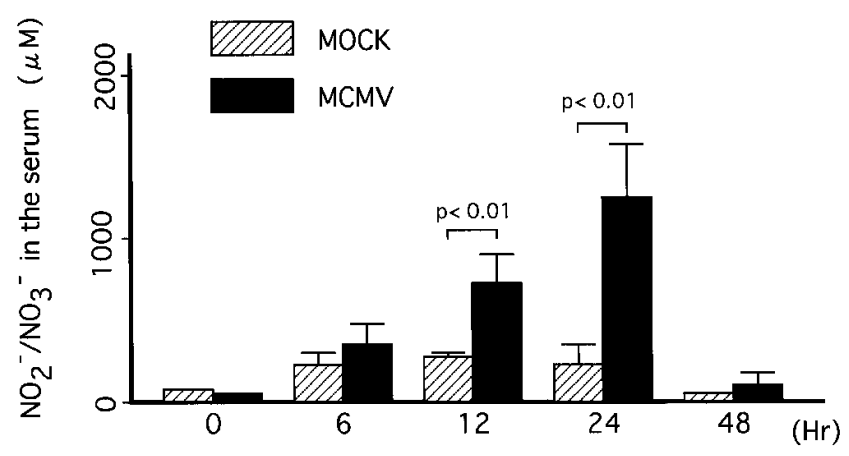

Figure 6. The serum levels of $\mathrm{NO}_{2}{ }^{-}$(nitrite) and $\mathrm{NO}_{3}{ }^{-}$(nitrate) in mice. The mice, which had been inoculated either with (black bar) or without (hatched bar) MCMV, were injected with anti-CD3 mAb. Next, the serum was collected at various intervals after the mAb injection as indicated in the figure. The serum levels of nitrite $\left(\mathrm{NO}_{2}{ }^{-}\right)$ and nitrate $\left(\mathrm{NO}_{3}{ }^{-}\right)$were measured by the method reported previously (14). The mean $\pm \mathrm{SD}, n=5-6$.

MCMV-infected mice provoked by the mAb were not mediated by reactive oxygen radicals.

Expression of iNOS $m R N A$. The next experiment was conducted to examine the involvement of NO in the inflammation of the lung. To assess the production level of NO, the expression level of iNOS mRNA in the lung was examined using RNA-PCR. As shown in Fig. 5, iNOS mRNA was totally undetectable in the lungs of the mock infected mice (upper panel), whereas it was abundantly expressed in the MCMV infected mice 6 to $24 \mathrm{~h}$ after the anti-CD3 injection and marginally expressed even at $0 \mathrm{~h}$ (lower panel). IFN- $\gamma$ together with the cooperation by TNF- $\alpha$ has been previously reported to induce the expression of the iNOS gene (31). Considering that the expression of iNOS mRNA in the lung after anti-CD3 injection (Fig. 5) was preceded by the expression of IFN- $\gamma$ and TNF- $\alpha$ mRNA (Fig. 2), it was thus suggested that IFN- $\gamma$ and TNF- $\alpha$ are inducers for the expression of iNOS mRNA in the lungs that developed interstitial pneumonitis. On the other hand, iNOS mRNA was undetectable at any time after the injection of $\mathrm{mAb}$ in the spleens of either the MCMV-infected or the mock infected mice (data not shown).
Serum levels of $\mathrm{NO}_{2}{ }^{-}$and $\mathrm{NO}_{3}{ }^{-}$. To confirm that a high expression level of iNOS mRNA in the lungs really caused an elevation in the production level of $\mathrm{NO}$, the serum levels of $\mathrm{NO}_{2}{ }^{-}$and $\mathrm{NO}_{3}{ }^{-}$, which are the metabolic product of $\mathrm{NO}$ in the aqueous phase, were measured. As shown in Fig. 6, the serum levels of $\mathrm{NO}_{2}{ }^{-}$and $\mathrm{NO}_{3}{ }^{-}$in the mock-infected mice (45.3 \pm 2.2 $\mu \mathrm{M})$ were comparable to those in the MCMV infected mice at $0 \mathrm{~h}(43.0 \pm 5.8 \mu \mathrm{M})$. Anti-CD3 mAb injection moderately elevated the serum levels of $\mathrm{NO}_{2}{ }^{-}$and $\mathrm{NO}_{3}{ }^{-}$at 6,12 , and $24 \mathrm{~h}$ after the $\mathrm{mAb}$ injection in the mock-infected mice (Fig. 6, hatched box). On the other hand, the mAb drastically elevated the serum levels of $\mathrm{NO}_{2}{ }^{-}$and $\mathrm{NO}_{3}{ }^{-}$in the MCMV-infected mice (Fig. 6, black box). At 12 and $24 \mathrm{~h}$ after the injection of $\mathrm{mAb}$, the levels in the MCMV-infected mice were significantly higher than those in the mock infected animals (720.9 \pm 149.6 versus $280.1 \pm 20.6, P<0.01 ; 1232.3 \pm 406.3$ versus $222.3 \pm 163.7 \mu \mathrm{M}, P<0.01$; respectively). Namely, antiCD3 mAb elevated the serum levels of $\mathrm{NO}_{2}{ }^{-}$and $\mathrm{NO}_{3}{ }^{-}$in the MCMV-infected mice to $\sim 6$ times of those in the mock infected mice at $24 \mathrm{~h}$ after the mAb injection. At $48 \mathrm{~h}$ after the injection of $\mathrm{mAb}$, the high levels returned to levels similar to those before the mAb injections both in the MCMV-infected and the mock-infected mice. Considering that serum levels of $\mathrm{NO}_{2}{ }^{-}$and $\mathrm{NO}_{3}{ }^{-}$in the normal mice were around $50 \mu \mathrm{M}$, it was possible that such amounts of $\mathrm{NO}_{2}{ }^{-}$and $\mathrm{NO}_{3}{ }^{-}$were $>20$ times higher, thus implying that these levels were hazardous. Therefore, it is plausible that $\mathrm{NO}$ was responsible for the provocation of the lung lesions, and the lung is thus presumably one of the main organs to produce NO.

Effects of $L-N A M E$ and PBN on MCMV-associated lung lesions. To further confirm that interstitial pneumonitis in this study was mediated by NO, L-NAME and PBN were applied in the next experiments. When the mice persistently infected with MCMV were injected with L-NAME, an inhibitor of NOS (12), $40 \%$ of the mice died without an injection of mAb (Table I), whereas none of the mock-infected mice died after the injection of L-NAME. Therefore, other materials were examined in the next experiments. PBN, which decreases the amount of iNOS (15), was applied. Without anti-CD3 treatment, an injection of PBN exerted no obvious effect on the lungs of the mock-infected or MCMV-infected mice by a histological analysis (data not shown), and none of those mice

Table I. Effect of PBN on Anti-CD3 mAb-induced Lung Lesions in MCMV-infected Mice

\begin{tabular}{|c|c|c|c|c|c|}
\hline MCMV* & Anti-CD $3^{\ddagger}$ & Agents & NO concentration in the serum $(\mu \mathrm{M})^{\S}$ & Mortality $(\%)^{\|}$ & $\left(\right.$Alveolar space/whole area) $\times 100(\%)^{\mathrm{q}}$ \\
\hline$(-)$ & $(-)$ & $(-)$ & $45.3 \pm 2.2 * *$ & 0 & $73.2 \pm 1.4$ \\
\hline$(+)$ & $(-)$ & $(-)$ & $43.0 \pm 5.8$ & 0 & ND \\
\hline$(+)$ & $(-)$ & L-NAME䘹 & ND & 40 & ND \\
\hline$(+)$ & $(-)$ & $\mathrm{PBN}^{\S \S}$ & ND & 0 & ND \\
\hline$(+)$ & $(+)$ & $(-)$ & $1232.9 \pm 406.3^{\|\|}$ & 60 & $26.9 \pm 2.4^{\pi} \pi$ \\
\hline$(+)$ & $(+)$ & PBN & $154.2 \pm 66.3^{\|\|}$ & 40 & $60.9 \pm 10.5^{\text {बाँ }}$ \\
\hline$(+)$ & $(+)$ & L-NAME & ND & 55.5 & ND \\
\hline
\end{tabular}

${ }^{*} \mathrm{BALB} / \mathrm{c}$ mice were inoculated intraperitoneally with $1 \times 10^{5} \mathrm{PFU}$ of MCMV at $4 \mathrm{wk}$ before. ${ }^{*} 50 \mu \mathrm{g}$ of anti-CD3 was injected intraperitoneally at $0 \mathrm{~h}$. ${ }^{8}$ Serum was collected at $24 \mathrm{~h}$ after the injection of anti-CD3, and its NO concentration was measured. "Death was determined at $24-48 \mathrm{~h}$ after antiCD3 injection, as it occurred during the period. "The ratio of [(alveolar space/whole area) $\times 100] \%$ was microscopically determined using a computer image analyzer, and applied as the indicator of interstitial thickening in the histology. **Mean $\pm \mathrm{SD}, n=4-11 .{ }^{*} 3 \mathrm{mg} / \mathrm{kg}(750 \mu \mathrm{g}$ per mouse) of L-NAME was injected intraperitoneally at 0 and $3 \mathrm{~h}$ after the injection of anti-CD3 mAb. ${ }^{\S} 750 \mathrm{mg}$ of PBN was injected intraperitoneally at $3 \mathrm{~h}$ after the injection of mAb. $\||| P<0.001$. ${ }^{\text {III }} P<0.001$. 

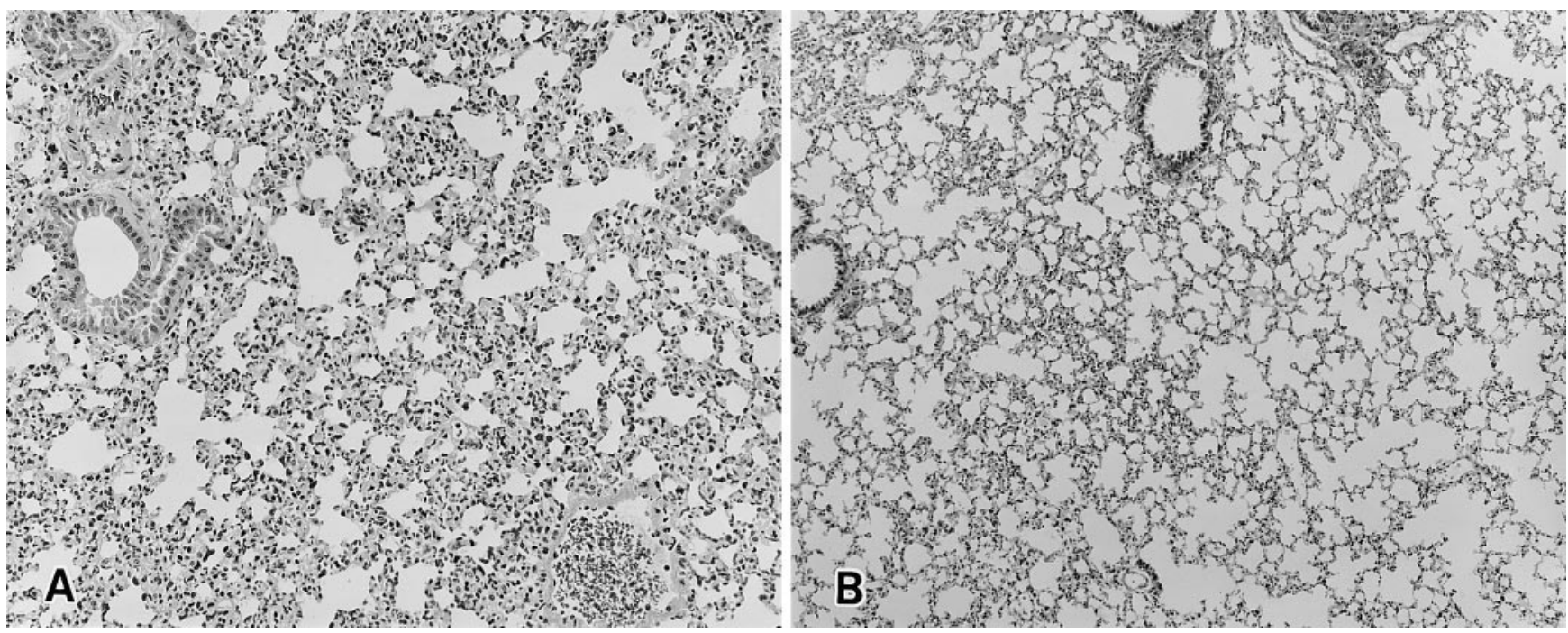

Figure 7. Effect of PBN on the histological findings of interstitial pneumonitis. The mice were inoculated with MCMV 4 wk earlier, and then were injected with $50 \mu \mathrm{g}$ of anti-CD3 $\mathrm{mAb}$. At $3 \mathrm{~h}$ after the $\mathrm{mAb}$ injection, $9 \mathrm{mg}$ of PBN was injected intraperitoneally into group B, but not group $\mathrm{A}$. The lungs were removed at $24 \mathrm{~h}$ after the mAb injection. Hematoxylin-eosin staining. $A, \times 150 ; B, \times 100$.

died after the administration of this agent (Table I). $9 \mathrm{mg}$ of $\mathrm{PBN}$, which was injected at $3 \mathrm{~h}$ after the injection of $50 \mu \mathrm{g}$ of anti-CD3 mAb, significantly reduced the serum levels of $\mathrm{NO}_{2}^{-}$ and $\mathrm{NO}_{3}{ }^{-}$from $1239.9 \pm 406.3 \mu \mathrm{M}$ to $154.2 \pm 66.3 \mu \mathrm{M}$ (Table I), and almost completely abrogated the effect of anti-CD3 to provoke interstitial lesions (Fig. 7). When the extent of opened alveolar space was estimated by a computer image analyzer, the PBN treatment significantly improved the ratio of the opened alveolar spaces from $26.9-60.9 \%$ (Table I). This result thus demonstrated that NO was responsible for the lung lesions induced by anti-CD3 $\mathrm{mAb}$ in MCMV-infected mice. However, the mortality was scarcely reduced (Table I), in spite of the complete improvement of the pulmonary lesions.

Determination of nitro-tyrosine/tyrosine ratio in the lung. Recently, NO has been reported to cause various inflammatory disorders such as alveolitis and arthritis (34-35). Though $\mathrm{NO}$ is one of the free radicals, its chemical reactivity is not strong enough to provoke severe tissue injury by itself (36). Thus, the pulmonary inflammation in this study was possibly mediated not by $\mathrm{NO}$ itself but by its chemical derivatives. Among the various NO-derived active substances, peroxynitrite $\left(\mathrm{ONOO}^{-}\right)$, has been shown to have a role in various inflammatory disorders (37-40). Based on the evidence that peroxynitrite nitrates tyrosine, the nitrotyrosine formation in the lung was examined. However, in contrast to our expectations, the nitrotyrosine formation was not elevated in MCMVinfected mice at $24 \mathrm{~h}$ after anti-CD3 injection (Fig. 8), suggesting NO-derived molecule(s) other than peroxynitrite was responsible for the pathogenesis of pneumonitis.

\section{Discussion}

In a previous report, it was demonstrated that MCMV-associated pneumonitis was provoked by the injection of anti-CD3 $\mathrm{mAb}$ in the lungs of mice persistently infected with MCMV (9). In this study, it was demonstrated that mRNA of such cytokines as IL-2, IL- 6 , TNF- $\alpha$, and IFN- $\gamma$ were abundantly expressed $3 \mathrm{~h}$ after the injection of $\mathrm{mAb}$ in the lungs that were free of MCMV, and that such high expressions thereafter continued until $12 \mathrm{~h}$. In addition, a marked induction of iNOS was observed in the lungs. Kinetic study of the expression of mRNA for cytokines and iNOS suggested that such as cytokines TNF- $\alpha$ and IFN- $\gamma$ induced iNOS. Accordingly, the serum levels of $\mathrm{NO}_{2}{ }^{-}$and $\mathrm{NO}_{3}{ }^{-}$markedly increased after the injection of $\mathrm{mAb}$. Moreover, the treatment to inhibit $\mathrm{NO}$

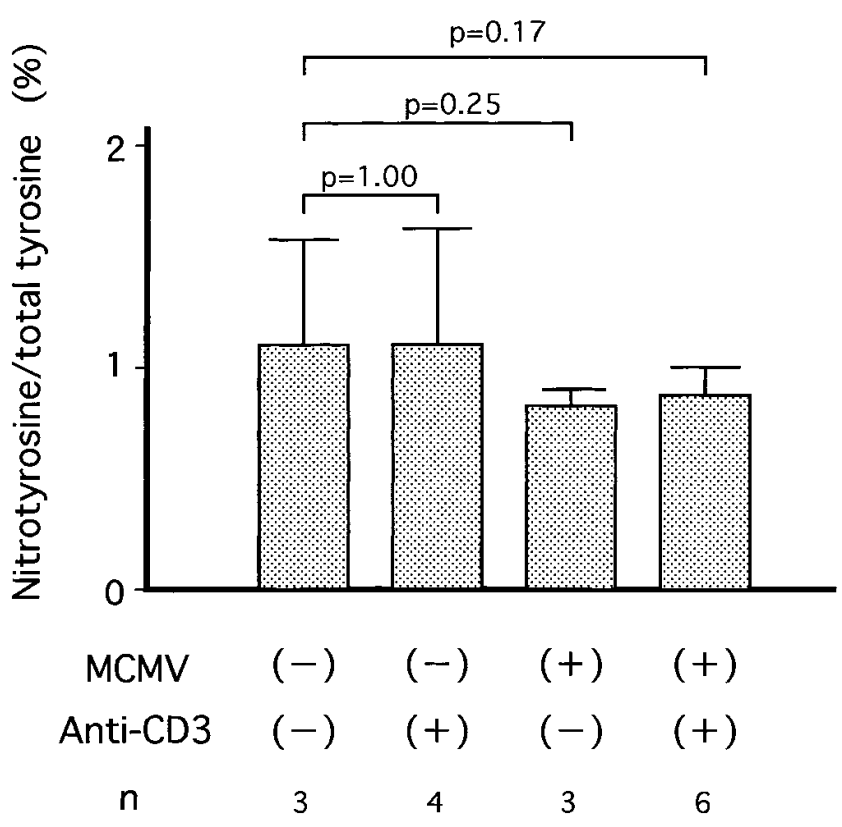

Figure 8. Tyrosine nitration in the mouse lungs. The mice, which had been infected with MCMV 4 wk earlier, were injected intraperitoneally with anti-CD3, and then the lungs were removed $24 \mathrm{~h}$ after the $\mathrm{mAb}$ injection. Tyrosine nitrated by peroxynitrite, and tyrosine without nitration were then separated by HAPLY, and were measured by an ultraviolet detector. Next, the nitrotyrosine/tyrosine ratio was calculated; $n=3-6$. 
production also inhibited the interstitial pneumonitis. The aim of this study was to clarify the pathogenesis of CMV-associated interstitial pneumonitis through these results.

One of the reasons why the lungs were targeted in this model is because of the fact that the lung is the major organ to produce cytokines. As shown in Fig. $2 A$, mRNA of cytokines such as IL-2, IL-6, IFN- $\gamma$ and TNF- $\alpha$ was abundantly expressed at $3 \mathrm{~h}$ after anti-CD3 injection and such abundant expressions were prolonged thereafter in the lungs of the MCMV-infected mice. In contrast, the expression levels of the cytokine mRNA were transient in the lungs of the mockinfected mice (Fig. $2 A$ ). Moreover, the expression levels of mRNA of IFN- $\gamma$ and TNF- $\alpha$ after the injection of $m A b$ were more abundant in the lung than in the spleen of the MCMVinfected mice (Fig. $2 \mathrm{~B}$ ). Thus, it seemed that the lungs produced a larger amount of cytokines than the spleens. The question as to why the induction of cytokines after the injection of anti-CD3 $\mathrm{mAb}$ predominated in the lungs remains to be clarified. One possibility is that the anti-CD3 injection accumulated the primed $\mathrm{T}$ cells in the lung, and then the mAb stimulated the primed T cells there. Actually, Anderson et al. (41) reported that IL-2-induced cytokines (IFN- $\gamma$ and TNF- $\alpha$ ), adhesion molecules, and chemokines such as RANTES (regulated on activation, normal $\mathrm{T}$ expressed and secreted) and MIP-1 $\alpha$ (macrophage inflammatory protein-1 $\alpha$ ) in the lung (41). Thus, it is plausible that anti-CD3 injection had an effect similar to that of IL-2 injection, resulting in the production of RANTES, which attracts memory phenotype T cells (42), in the lung. Moreover, it was observed that a large amount of RANTES was produced during CMV pneumonitis in transplant recipients (43). This process may explain why the lung was the major organ to produce cytokines.

As shown in Fig. 5, mRNA for iNOS was abundantly expressed in the lungs of the MCMV-infected mice from 6 to $24 \mathrm{~h}$ after the injection of $\mathrm{mAb}$, which was supported by the marked increase of the serum levels of nitrite and nitrate. Since mRNA for IFN- $\gamma$ and TNF- $\alpha$ were abundantly expressed $3 \mathrm{~h}$ after the injection of $\mathrm{mAb}$, and that such high expression levels continued in the lungs of MCMV until $12 \mathrm{~h}$ after the mAb injection, iNOS was induced by IFN- $\gamma$ and TNF- $\alpha$. These results also correlated with those from a previous report demonstrating that IFN- $\gamma$ and TNF- $\alpha$ induce iNOS (31). Considering that the lungs in MCMV-infected mice seemed to be the major organ to produce IFN- $\gamma$ and TNF- $\alpha$ after anti-CD3 $\mathrm{mAb}$ injection, the predominance of the induction of iNOS mRNA in the lungs after the injection of $\mathrm{mAb}$ thus appears to be the logical outcome. Furthermore, the lungs also have an abundance of resident or adhering mononuclear cells, which are the major source of NO, thus suggesting the lung to be the major organ for NO production. Similar results were obtained in the model of endotoxin shock. In the rats treated with LPS, NO was predominantly produced in the lungs, with the concomitant induction of such cytokines as IFN- $\gamma$ and TNF- $\alpha$ (44). The predominance of iNOS induction in the lungs was explained by the fact that not only mononuclear cells in the lungs, but also pulmonary endothelial cells and pulmonary vascular smooth muscle cells were prone to induce iNOS (44). Taken together, it can be concluded that NO is involved in MCMV-associated pneumonitis.

Above conclusion was confirmed by the studies in which NO synthesis was inhibited by L-NAME or PBN. Although L-NAME has been widely used as an iNOS inhibitor, the injec- tion of L-NAME to mice persistently infected with MCMV resulted in $40 \%$ death without an mAb injection. None of the mock-infected mice died of the same dose of L-NAME. As L-NAME significantly reduces the perfusion of all organs by inhibiting the NO action of the endothelial derived relaxing factor (EDRF) function (45), this effect of L-NAME would be fatal in MCMV-infected mice, whose hemodynamics were altered even before the anti-CD3 injection. Therefore, PBN, of which the major action is shown to inhibit iNOS mRNA (15), was mainly used in this study, as none of the mice treated with this material died when the mAb was not injected. As shown in Table I and Fig. 7, PBN completely improved the histology of the lung lesions. This finding confirmed that the interstitial pneumonitis in the present model was provoked by NO. However, in spite of the improvement in histology, PBN scarcely reduced the mortality (Table I). This result raised the possibility that the cytokine-mediated, but not NO-mediated, injury is fatal in the present model. Thus, if this hypothesis was a fact, then other organ(s) than the lungs would seem to be responsible for death.

Since NO itself is not an active molecule, the identification of the cytotoxic molecule responsible for the NO-mediated lung lesions was examined in the next step. Various NOderived active molecules are reported to exert deleterious effects in vivo in pathological conditions (36). Among the molecules, peroxynitrite $\left(\mathrm{ONOO}^{-}\right)$, a reaction product of $\mathrm{NO}$ and superoxide $\left(\mathrm{NO} / \mathrm{O}_{2}{ }^{-}\right)$, seemed to be the most plausible candidate, since this material is a potent oxidant and its protonated form is as reactive as hydroxyl radical in vivo (38-39). Thus, peroxynitrite-induced injury in the lung was estimated in this study by measuring the formation of nitrotyrosine. Unexpectedly, nitrotyrosine was not increased in the lungs with severe pneumonitis (Fig. 8). Moreover, the $\mathrm{O}_{2}{ }^{-}$generation in the BAL of MCMV-infected mice was comparable to those in mockinfected mice (Fig. 4), suggesting that an NO-derived active molecule other than peroxynitrite would be responsible for the generation of interstitial pneumonitis in the present model. One of the other candidates is nitric dioxide $\left(\mathrm{NO}_{2}\right)$, which is formed by a reaction of $\mathrm{NO}$ and oxygen $\left(\mathrm{NO} / \mathrm{O}_{2}\right)$. Considering that oxygen concentration is extremely high in the lung tissues compared to other tissues, the $\mathrm{NO} / \mathrm{O}_{2}$ reaction is likely to occur in the lungs, leading to the formation of $\mathrm{NO}_{2}$, which can nitrosate sulfhydryls and oxidize various substrates. However, its generation and the injurious effect on the tissue remain to be examined.

In conclusion, in the present model of interstitial pneumonitis, anti-CD3 induced the production of cytokines such as IFN- $\gamma$ and TNF- $\alpha$ in the lungs of the MCMV-infected mice. These cytokines thus induced NO, and then NO provoked MCMV-associated interstitial pneumonitis. These new findings in an animal model are considered to contribute a great deal both in making a diagnosis and in treating clinical CMV pneumonitis, which is a severe complication in transplantation patients.

\section{References}

1. Grundy, J.E., J.D. Shanley, and P.D. Griffith. 1987. Is cytomegalovirus interstitial pneumonitis in transplant recipients an immunological condition? Lancet. 2:996-1000.

2. Zaia, J.A. 1991. Pathogenesis of CMV-associated disease in 1990. Transplant. Proc. 23:1-4.

3. Forman, S.J. Bone marrow transplantation. Transplant. Proc. 23:110-114. 
4. Broaddus, C., M.D. Dake, M.S. Stulbarg, W. Blumenfeld, W.K. Handley, J.A. Golden, and P.C. Hopewell. 1985. Bronchoalveolar lavage and transbronchial biopsy for the diagnosis of pulmonary infections in the acquired immunodeficiency syndrome. Ann. Intern. Med. 102:747-752.

5. Jacobson, M.A., and J. Mills. 1988. Serious cytomegalovirus disease in the acquired immunodeficiency syndrome (AIDS). Ann. Intern. Med. 108:585594.

6. Gallant, J.E., R.D. Moore, D.D. Richman, J. Keruly, R.E. Chaisson, and the Zidovudine Epidemiology Study Group. 1992. Incidence and natural history of cytomegalovirus disease in patients with advanced human immunodeficiency virus disease treated with zidovudine. J. Infect. Dis. 166:1223-1227.

7. Rubin, R.H. 1994. Infection in the organ transplant recipient. In Clinical Approach to Infection in the Compromised Host (3rd. Ed). R.H. Rubin and L.S. Young, editors. Plenum Publishing Corp., New York. 629-705.

8. Bowden, R.A., and J.D. Meyers. 1994. Infectious complicating bone marrow transplantation. In Clinical Approach to Infection in the Compromised Host (3rd. Ed). R.H. Rubin and L.S. Young, editors. Plenum Publishing Corp., New York. 601-628.

9. Tanaka, K., Y. Koga, Y.-Y. Lu, X.-Y. Zhang, Y. Wang, G. Kimura, and K. Nomoto. 1994. Murine cytomegalovirus-associated pneumonitis in the lungs free of the virus. J. Clin. Invest. 94:1019-1025.

10. Hirsch, R., R.E. Gress, D.H. Pluznik, M. Eckhaus, and J.A. Bluestone. 1989. Effects of in vivo administration of anti-CD3 monoclonal antibody on T cell function in mice. II. In vivo activation of T cells. J. Immunol. 142:737-743.

11. Lukacs, N.W., and P.A. Ward. 1996. Inflammatory mediators, cytokines, and adhesion molecules in pulmonary inflammation and injury. Adv. Immunol. 62:257-304.

12. Schmidt, H.H.H.W., and U. Water. 1994. NO at work. Cell. 78:919-925.

13. Igarashi, R., J. Hoshino, M. Takenaga, S. Kawai, Y. Morizawa, A. Yasuda, M. Otani, and Y. Mizushima. 1992. Lecithinization of superoxide dismutase potentiates its protective effect against Forssman antiserum-induced elevation in guinea pig airway resistance. J. Pharmacol. Exp. Ther. 262:1214-1219.

14. Buisson, A., I. Margaill, J. Callebert, M. Plotkine, and R.G. Boul. 1993. Mechanisms involved in the neuroprotective activity of a nitric oxide synthetase inhibitor during focal cerebral ischemia. J. Neurochem. 61:690-699.

15. Miyajima, T., and Y. Kotake. 1995. Spin trapping agent, phenyl N-tertbutyl nitrone, inhibits induction of nitric oxide synthetase in endotoxin-induced shock in mice. Biochem. Biophys. Res. Commun. 215:114-121.

16. Kashima, N., C. Nishi-Takaoka, T. Fujita, S. Taki, G. Yamada, J. Hamuro, and T. Taniguchi. 1985. Unique structure of murine interleukin-2 as deduced from cloned cDNAs. Nature (Lond.). 313:402-404.

17. Van-Snick, J., S. Cayphas, J.P. Szikora, J.C. Renauld, E. Van-Roost, T. Boon, and R.J. Simpson. 1988. cDNA cloning of murine interleukin-HP1: homology with human interleukin 6. Eur. J. Immunol. 18:193-197.

18. Pennica, D., J.S. Hayflick, T.S. Bringman, M.A. Palladino, and D.V. Goeddel. 1985. Cloning and expression in Escherichia coli of the cDNA for murine tumor necrosis factor. Proc. Natl. Acad. Sci. USA. 82:6060-6064.

19. Gray, P.W., and D.V. Goeddel. 1983. Cloning and expression of murine immune interferon cDNA. Proc. Natl. Acad. Sci. USA. 82:5842-5846.

20. Alonson, S., A. Minty, Y. Bourlet, and M. Buckingham. 1986. Comparison of three actin-coding sequences in the mouse; evolutionary relationships between the actin genes of warm-blooded vertebrates. J. Mol. Evol. 23:1-22.

21. Lyons, C.R., G.J. Orloff, and J.M. Cunningham. 1992. Molecular cloning and functional expression of an inducible nitric oxide synthetase from a murine macrophage cell line. J. Biol. Chem. 267:6370-6374.

22. Haining, J.L., and J.S. Legan. 1967. Fluorometric assay for xanthine oxidase. Anal. Chem. 21:337-343.

23. Guarner, C., G. Soriano, A. Thomas, O. Bulbena, M.T. Novella, J. Balanzo, F. Vilardell, M. Mourelle, and S. Moncada. 1993. Increased serum nitrite and nitrate levels in patients with cirrhosis: Relationship to toxemia. Hepatology. 18:1139-1143.

24. Fukuyama, N., K. Ichimori, Z. Su, H. Ishida, and H. Nakazawa. 1996. Peroxynitrite formation from activated human leukocytes. Biochem. Biophys. Res. Commun. 224:414-419.

25. Gow, A.J., D. Duran, S. Malcolm, and H. Ischiropoulos. 1996. Effect of peroxynitrite-induced protein modifications on tyrosine phosphorylation and degradation. FEBS Lett. 385:63-66.

26. Kaur, H., and B. Halliwell. 1994. Evidence for nitric oxide-mediated oxidative damage in chronic inflammation. Nitrotyrosine in serum and synovial fluid from rheumatoid patients. FEBS Lett. 350:9-12.

27. Nathan, C.F., H.W. Murray, M.E. Wiebe, and B.Y. Rubin. 1983. Identification of interferon- $\gamma$ as the lymphokine that activates human macrophage oxidative metabolism and antimicrobial activity. J. Exp. Med. 158:670-689.

28. Nathan, C.F., C.R. Horowitz, J. de la Harpe, S. Vadhan-Raj, S.A. Sherwin, H.F. Oettgen, and S.E. Krown. 1985. Administration of recombinant interferon- $\gamma$ to cancer patients enhances monocyte secretion of hydrogen peroxide. Proc. Natl. Acad. Sci. USA. 82:8686-8690.

29. Berton, G., L. Zemi, M.A. Cassatella, and F. Rossi. 1986. Gamma interferon is able to enhance the oxidative metabolism of human neutrophils. Biochem. Biophys. Res. Commun. 138:1276-1282.

30. Badger, A.M. 1986. Enhanced superoxide production by rat alveolar macrophage stimulated in vitro with biological response modifiers. J. Leukocyte Biol. 40:725-736.

31. Deng, W., B. Thiel, C.S. Tannenbaum, T.A. Hamilton, and D.J. Stuer. 1993. Synergistic cooperation between T cell lymphokines for induction of the nitric oxide synthetase gene in murine peritoneal macrophages. J. Immunol. 151:322-329.

32. Cox, G.W., G. Mellio, U. Chattopadhyay, D. Mullet, R.H. Fertel, and L. Varesio. 1992. Tumor necrosis factor-a-dependent production of reactive nitrogen intermediates mediates IFN- $\gamma$-plus IL-2-induced murine macrophage tumoricidal activity. J. Immunol. 149:3290-3296.

33. Green, S.J., R.M. Crawford, J.T. Hockmeyer, M.S. Meltzer, and C.A. Nacy. 1990. Leishmania major amastigotes initiate the L-arginine-dependen killing mechanism in IFN- $\gamma$-stimulated macrophages by induction of tumor necrosis factor- $\alpha$. J. Immunol. 145:4290-4297.

34. Mulligan, M.S., J.M. Hevel, M.A. Marletta, and P.A. Ward. 1991. Tissue injury caused by deposition of immune complex is L-arginine dependent. Proc Natl. Acad. Sci. USA. 88:6338-6342.

35. McCartney-Francis, N., J.B. Allen, D.E. Mizel, J.E. Albina, Q.-W. Xie, C.F. Nathan, and S.M. Wahl. 1993. Suppression of arthritis by an inhibitor of nitric oxide synthetase. J. Exp. Med. 178:749-754

36. Wink, D.A., M.B. Grisham, J.B. Mitchell, and P.C. Ford. 1996. Direct and indirect effects of nitric oxide in chemical reactions relevant to biology. In Methods in Enzymology. Vol. 268. Nitric oxide. Part A. Sources and detection of NO; NO synthetase. L. Parker, editor. Academic Press, Inc., San Diego, CA. $12-31$.

37. Ischiropoulos, H., L. Zhu, and J.S. Beckman. 1992. Peroxynitrite formation from macrophage-derived nitric oxide. Arch. Biochem. Biophys. 198:431437.

38. Xia, Y., V.L. Dawson, T.M. Dawson, S.H. Snyder, and J.L. Zweier. 1996. Nitric oxide synthetase generates superoxide and nitric oxide in argininedepleted cells leading to peroxynitrite-mediated cellular injury. Proc. Natl. Acad. Sci. USA. 93:6770-6774.

39. Akaike, T., Y. Noguchi, S. Ijiri, K. Setoguchi, M. Suga, Y.M. Zheng, B. Dietzschold, and H. Maeda. 1996. Pathogenesis of influenza virus-induced pneumonia: involvement of both nitric oxide and oxygen radicals. Proc. Natl. Acad. Sci. USA. 93:2448-2453.

40. Crow, J.P., and J.S. Beckman. 1995. The role of peroxynitrite in nitric oxide-mediated toxicity. In The Role of Nitric Oxide in Physiology and Pathophysiology. K. Koprowski and H. Maeda, editors. Springer-Verlag, Berlin. 5774.

41. Anderson, J.A., A.B. Lentsch, D.J. Hadjiminas, F.N. Miller, A.W. Martin, K. Nakagawa, and M.J. Edwards. 1996. The role of cytokines, adhesion molecules, and chemokines in interleukin-2-induced lymphocytic infiltration in C57BL/6 mice. J. Clin. Invest. 97:1952-1959.

42. Schall, T.J., K. Bacon, K.J. Toy, and D.V. Goeddel. 1990. Selective attraction of monocytes and $\mathrm{T}$ lymphocytes of the memory phenotype by cytokine RANTES. Nature (Lond.). 347:669-671.

43. Monti, G., A. Magnan, M. Fattal, B. Rain, M. Humbert, J.-L. Mege, M. Noirclerc, P. Dartevelle, J. Cerrina, G. Simonneau, et al. 1996. Intrapulmonary production of RANTES during rejection and CMV pneumonitis after lung transplantation. Transplantation. 61:1757-1762.

44. Szabo, C. 1995. Alterations in nitric oxide production in various forms of circulatory shock. New Horizons. 3:2-32.

45. Yamashita, T., I. Kuwahira, S. Harasawa, T. Miwa, T. Oka, H. Mori, and H. Nakazawa. 1996. Role of EDRF/NO in regional vascular resistance in pharmacologically denervated rats. Pathophysiology. 3:149-156. 